University of Nebraska - Lincoln

DigitalCommons@University of Nebraska - Lincoln

\title{
Solution and Microbial Controls on the Formation of Reduced U(IV) Species
}

\author{
Maxim I. Boyanov \\ Argonne National Laboratory \\ Kelly E. Fletcher \\ Georgia Institute of Technology \\ Man Jae Kwon \\ Argonne National Laboratory \\ Xue Rui \\ University of Notre Dame \\ Edward J. O'Loughlin \\ Argonne National Laboratory \\ See next page for additional authors
}

Follow this and additional works at: https://digitalcommons.unl.edu/usdoepub

Part of the Bioresource and Agricultural Engineering Commons

\footnotetext{
Boyanov, Maxim I.; Fletcher, Kelly E.; Jae Kwon, Man; Rui, Xue; O'Loughlin, Edward J.; Löffler, Frank E.; and Kemner, Kenneth M., "Solution and Microbial Controls on the Formation of Reduced U(IV) Species" (2011). US Department of Energy Publications. 137.

https://digitalcommons.unl.edu/usdoepub/137

This Article is brought to you for free and open access by the U.S. Department of Energy at DigitalCommons@University of Nebraska - Lincoln. It has been accepted for inclusion in US Department of Energy Publications by an authorized administrator of DigitalCommons@University of Nebraska - Lincoln.
} 


\section{Authors}

Maxim I. Boyanov, Kelly E. Fletcher, Man Jae Kwon, Xue Rui, Edward J. O'Loughlin, Frank E. Löffler, and Kenneth M. Kemner 


\title{
Solution and Microbial Controls on the Formation of Reduced U(IV) Species
}

\author{
Maxim I. Boyanov, ${ }^{*+}{ }^{\dagger}$ Kelly E. Fletcher, ${ }^{\ddagger}$ Man Jae Kwon, ${ }_{+}^{+, \nabla}$ Xue Rui, ${ }^{\S}$ Edward J. O’Loughlin, ${ }^{\dagger}$ \\ Frank E. Löffler, ${ }^{\|, \perp}, \#$ and Kenneth M. Kemner ${ }^{+}$ \\ ${ }^{\dagger}$ Biosciences Division, Argonne National Laboratory, Argonne, Illinois 60439, United States \\ ${ }^{\ddagger}$ School of Civil and Environmental Engineering, Georgia Institute of Technology, Atlanta, Georgia 30332, United States \\ ${ }_{\S}^{\S}$ Department of Physics, University of Notre Dame, Notre Dame, Indiana 46545, United States \\ ${ }^{\|}$Department of Microbiology and ${ }^{\perp}$ Department of Civil and Environmental Engineering, University of Tennessee, Knoxville, \\ Tennessee 37996, United States \\ \#Biosciences Division, Oak Ridge National Laboratory, Oak Ridge, Tennessee 37831, United States
}

Supporting Information

\begin{abstract}
Reduction of $\mathrm{U}^{\mathrm{VI}}$ to $\mathrm{U}^{\mathrm{IV}}$ as the result of direct or indirect microbial activity is currently being explored for in situ remediation of subsurface $U$ plumes, under the assumption that $\mathrm{U}^{\mathrm{IV}}$ solubility is controlled by the lowsolubility mineral uraninite ( $\mathrm{U}^{\mathrm{IV}}$-dioxide). However, recent characterizations of $\mathrm{U}$ in sediments from biostimulated field sites, as well as laboratory $\mathrm{U}^{\mathrm{VI}}$ bioreduction studies, report on the formation of $\mathrm{U}^{\mathrm{IV}}$ species that lack the $\mathrm{U}=\mathrm{O}_{2}=\mathrm{U}$ coordination of uraninite, suggesting that phases other than uraninite may be controlling $\mathrm{U}^{\mathrm{IV}}$ solubility in environments with complexing surfaces and ligands. To determine the controls on the formation of such nonuraninite $\mathrm{U}^{\mathrm{IV}}$ species, the current work studied the reduction of carbonate-complexed $\mathrm{U}^{\mathrm{VI}}$ by (1) five Gram-positive Desulfitobacterium strains, (2) the Gram-negative bacteria Anaeromyxobacter dehalogenans 2CP-C and Shewanella putrefaciens CN32, and (3) chemically reduced 9,10-anthrahydroquinone-2,6-disulfonate $\left(\mathrm{AH}_{2} \mathrm{QDS}\right.$, a

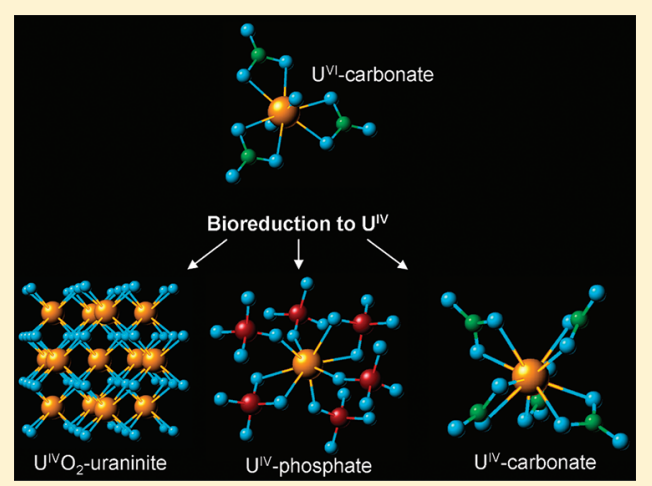
soluble reductant). Further, the effects of $0.3 \mathrm{mM}$ dissolved phosphate on $\mathrm{U}^{\mathrm{IV}}$ species formation were explored. Extended X-ray absorption fine structure (EXAFS) spectroscopy analysis demonstrated that the addition of phosphate causes the formation of a nonuraninite, phosphate-complexed $\mathrm{U}^{\mathrm{IV}}$ species, independent of the biological or abiotic mode of $\mathrm{U}^{\mathrm{VI}}$ reduction. In phosphate-free medium, $\mathrm{U}^{\mathrm{VI}}$ reduction by Desulfitobacterium spp. and by $\mathrm{AH}_{2} \mathrm{QDS}$ resulted in nonuraninite, carbonate-complexed $\mathrm{U}^{\mathrm{V}}$ species, whereas reduction by Anaeromyxobacter or Shewanella yielded nanoparticulate uraninite. These findings suggest that the Grampositive Desulfitobacterium strains and the Gram-negative Anaeromyxobacter and Shewanella species use distinct mechanisms to reduce $\mathrm{U}^{\mathrm{VI}}$.
\end{abstract}

\section{INTRODUCTION}

Power generation, nuclear weapons production, and weathering of uranium-containing natural minerals has resulted in widespread uranium contamination of aquatic and terrestrial environments. ${ }^{1-3}$ Under oxic conditions uranium is typically present as uranyl $\mathrm{U}^{\mathrm{VI}} \mathrm{O}_{2}{ }^{2+}$, a form that is generally soluble and mobile in groundwater. Uranium solubility is significantly lower in the presence of phosphate because of uranyl phosphate precipitation or under reducing conditions that favor transformation of $\mathrm{U}^{\mathrm{VI}}$ to sparingly soluble $\mathrm{U}^{\mathrm{IV}}$ species such as uraninite. ${ }^{4}$ In subsurface environments, a variety of redox and complexation reactions can occur, so the mobility of uranium will be controlled by many interconnected processes. Regardless of the immobilization pathway, it is important to identify the immobilized uranium species, because their distinct properties will affect uranium stability and mobility. Current $U$ transport models assume the formation of uraninite when accounting for reduced $\mathrm{U}^{\mathrm{IV}}$ species. ${ }^{5}$ However, a recent study examining $\mathrm{U}$ speciation in biostimulated field-site sediments determined a mixture of uraninite and $\mathrm{Fe}$-associated $\mathrm{U}^{\mathrm{IV}}$ species in the reduced $\mathrm{U}$ fraction. ${ }^{6}$

Many dissimilatory metal-reducing bacteria (DMRB) have been shown to reduce $\mathrm{U}^{\mathrm{VI}}$ under anoxic conditions and therefore can affect $U$ fate and mobility in subsurface environments. Both Gram-positive and Gram-negative $U^{\mathrm{VI}}$ reducing bacteria, such as Desulfitobacterium and Anaeromyxobacter, have been identified at field sites. ${ }^{7,8}$ The known differences between the cell envelopes of Gram-positive and Gram-negative bacteria have been

\footnotetext{
Received: April 24, 2011

Accepted: August 16, 2011

Revised: August 15, 2011

Published: August 16, 2011
} 
Table 1. Final U Concentrations in the Solution Phase and $\mathrm{U}^{\mathrm{IV}} / \mathrm{U}_{\text {total }}$ Ratios in the Solid Phase ${ }^{a}$

\begin{tabular}{|c|c|c|c|c|}
\hline reductant & reaction (days) & $\mathrm{U}^{\mathrm{VI}}$ final $(\mu \mathrm{M})^{b}$ & $\mathrm{U}^{\mathrm{IV}} / \mathrm{U}_{\text {tot }}(\%)^{c}$ & $\mathrm{U}^{\mathrm{IV}}$ speciation $^{d}$ \\
\hline \multicolumn{5}{|c|}{ Phosphate-Amended Medium } \\
\hline Desulfitobacterium, Co23 & 14 & $7(7 \%)$ & $>95$ & $\mathrm{U}^{\mathrm{IV}}$-phosphate \\
\hline Desulfitobacterium, JW/IU-DC1 & 16 & $6(6 \%)$ & $>95$ & $\mathrm{U}^{\mathrm{IV}}$-phosphate \\
\hline Desulfitobacterium, JH1 & 17 & $13(13 \%)$ & $>95$ & $\mathrm{U}^{\mathrm{IV}}$-phosphate \\
\hline Desulfitobacterium, PCE1 & 18 & $5(5 \%)$ & $>95$ & $\mathrm{U}^{\mathrm{IV}}$-phosphate \\
\hline Desulfitobacterium, Viet1 & 20 & $22(22 \%)$ & $>95$ & $\mathrm{U}^{\mathrm{IV}}$-phosphate \\
\hline Anaeromyxobacter, 2CP-C & 15 & nd $(0 \%)$ & $>95$ & $\mathrm{U}^{\mathrm{IV}}$-phosphate \\
\hline Shewanella, $\mathrm{CN} 32^{e}$ & 17 & nd $(0 \%)$ & $>95$ & $\mathrm{U}^{\mathrm{IV}}$-phosphate \\
\hline $\mathrm{AH}_{2} \mathrm{QDS}$ & 4 & $19(19 \%)$ & $>95$ & $\mathrm{U}^{\mathrm{IV}}$-phosphate \\
\hline no reductant (control) & 14 & $89(89 \%)$ & - & \\
\hline \multicolumn{5}{|c|}{ Phosphate-Free Medium } \\
\hline Desulfitobacterium, Co23 & 14 & $58(58 \%)$ & $>95$ & $62 \% \mathrm{U}^{\mathrm{IV}}$-carbonate $/ 38 \%$ nano-uraninite \\
\hline Desulfitobacterium, JW/IU-DC1 & 12 & $79(79 \%)$ & $>95$ & $62 \% \mathrm{U}^{\mathrm{IV}}$-carbonate $/ 38 \%$ nano-uraninite \\
\hline Desulfitobacterium, JH1 & 15 & $51(51 \%)$ & $>95$ & $62 \% \mathrm{U}^{\mathrm{IV}}$-carbonate $/ 38 \%$ nano-uraninite \\
\hline Desulfitobacterium, PCE1 & 12 & $72(72 \%)$ & $>95$ & $62 \% \mathrm{U}^{\mathrm{IV}}$-carbonate $/ 38 \%$ nano-uraninite \\
\hline Desulfitobacterium, Viet1 & 12 & $75(75 \%)$ & $>95$ & $62 \% \mathrm{U}^{\mathrm{IV}}$-carbonate $/ 38 \%$ nano-uraninite \\
\hline Anaeromyxobacter, 2CР-C & 15 & $69(92 \%)$ & $>95$ & $100 \%$ nano-uraninite \\
\hline Shewanella, MR-1 ${ }^{f}$ & $1-10$ & nd $(0 \%)$ & $>80$ & $100 \%$ nano-uraninite \\
\hline $\mathrm{AH}_{2} \mathrm{QDS}$ & 4 & $56(56 \%)$ & $>95$ & $62 \% \mathrm{U}^{\mathrm{IV}}$-carbonate $/ 38 \%$ nano-uraninite \\
\hline no reductant (control) & 14 & $94(94 \%)$ & - & \\
\hline \multicolumn{5}{|c|}{$\begin{array}{l}{ }^{a} \text { Phosphate medium }=290 \mu \mathrm{M} \text { phosphate. nd }=\text { none detected, }<0.1 \mu \mathrm{M} .{ }^{b} \text { Added } \mathrm{U}^{\mathrm{VI}} \text { concentration was } 100 \mu \mathrm{M} \text {, except for Anaeromyxobacter }(75 \\
\mu \mathrm{M}) \text {. Final } \mathrm{U}^{\mathrm{VI}} \text { concentrations in } 0.22-\mu \mathrm{m} \text { filtrates. The percentage of the added } \mathrm{U} \text { that remained in solution is shown in parentheses. Concentrations are } \\
\text { reported as the average from triplicate ICP-OES measurements. Standard deviation among the three measurements was } 0.1-0.3 \mu \mathrm{M} \text {. }{ }^{c} \text { Percentage of } \\
\text { solid-phase } \mathrm{U} \text { as } \mathrm{U}^{\mathrm{IV}} \text { from XANES. }{ }^{d} \text { In } 4.0 \mathrm{mM} \text { phosphate medium. }{ }^{e} \text { Experiments performed in } 4 \mathrm{mM} \text { phosphate-amended medium. }{ }^{f} \text { Results from } \\
\text { Burgos et al. }{ }^{19}\end{array}$} \\
\hline
\end{tabular}

hypothesized to result in different electron transfer mechanisms, ${ }^{9}$ which in turn suggests the possibility of distinct $\mathrm{U}^{\mathrm{IV}}$ species formation. $\mathrm{U}^{\mathrm{VI}}$ reduction has been studied in Gram-negative bacteria such as Geobacter spp., Shewanella spp., and Anaeromyxobacter spp. ${ }^{8,10-13}$ Fewer studies have investigated $U^{\mathrm{VI}}$ reduction by Gram-positive bacteria such as Clostridium, Desulfitobacterium, Desulfosporosinus, and Desulfotomaculum. ${ }^{7,14-17}$ Under diverse solution conditions, uranyl reduction by Shewanella, Anaeromyxobacter, and Geobacter spp. results in the formation of nanoparticulate uraninite (nano-uraninite). ${ }^{18-21}$ The formation of nanouraninite has been established by transmission electron microscopy/selective area electron diffraction and/or by the amplitude of the $\mathrm{U}-\mathrm{U}$ coordination peak in uranium $\mathrm{L}_{\mathrm{III}}$-edge extended $\mathrm{X}$-ray absorption fine structure (EXAFS) spectra. ${ }^{16,18,19,22-24}$ However, in several studies with Gram-positive bacteria the $\mathrm{U}-\mathrm{U}$ peak in the EXAFS spectra was not pronounced, suggesting the presence of $\mathrm{U}^{\mathrm{IV}}$ species that are different from those found in uraninite. ${ }^{7,15,16,25,26}$ A previous study reported a lack of $\mathrm{U}-\mathrm{U}$ coordination between the $\mathrm{U}^{\mathrm{IV}}$ atoms produced by Desulfitobacterium isolates, but the ligand coordination could not be conclusively established. ${ }^{7}$

In the current study, the atomic coordination of $\mathrm{U}^{\mathrm{IV}}$ produced biotically and abiotically in phosphate-free or phosphateamended medium was investigated. The biotic reduction pathway was examined with five Desulfitobacterium strains, Shewanella putrefaciens CN32, and Anaeromyxobacter dehalogenans 2CP-C, whereas the abiotic $\mathrm{U}^{\mathrm{IV}}$ species were produced in solution by using 9,10-anthrahydroquinone-2,6-disulfonate $\left(\mathrm{AH}_{2} \mathrm{QDS}\right.$, a soluble reductant carrying two electron equivalents). The goals were (1) to establish the effect of solution composition on $\mathrm{U}^{\mathrm{IV}}$ species formation, (2) to assign weak or overlapping EXAFS spectral features to ligand coordination by comparing nonuraninite $\mathrm{U}^{\mathrm{IV}}$ species produced under distinct conditions, and (3) to compare the $\mathrm{U}^{\mathrm{IV}}$ products formed by Gram-positive Desulfitobacterium and Gram-negative Anaeromyxobacter species and assess whether any differences can be related to $\mathrm{U}^{\mathrm{VI}}$ reduction mechanisms. These bacterial species were chosen as Grampositive and Gram-negative representatives identified at field sites, and S. putrefaciens $\mathrm{CN} 32$ was included for comparison to a broadly studied bacterium.

\section{MATERIALS AND METHODS}

Experimental Procedures. Desulfitobacterium chlororespirans strain Co23, Desulfitobacterium dehalogenans strain JW/IU-DC1, Desulfitobacterium hafniense strain JH1, Desulfitobacterium strain PCE1, and Desulfitobacterium strain Viet1 were inoculated into $30 \mathrm{mM}$ bicarbonate-buffered medium ( $\mathrm{pH}$ 6.8) containing $10 \mathrm{mM}$ pyruvate, $290 \mu \mathrm{M} \mathrm{KH}_{2} \mathrm{PO}_{4}, 100 \mu \mathrm{M} \mathrm{CaCl}$, and trace minerals. Cultures were incubated until visibly turbid and then amended with an additional $10 \mathrm{mM}$ pyruvate and $100 \mu \mathrm{M} \mathrm{U}^{\mathrm{VI}}$ and incubated for 14-20 days. Replicate cultures were established with phosphate-free medium (same medium composition without $\mathrm{KH}_{2} \mathrm{PO}_{4}$ ), but traces of phosphate sufficient for growth were transferred with the inocula. Experiments with $A$. dehalogenans strain 2CP-C were conducted similarly in $30 \mathrm{mM}$ bicarbonate-buffered medium amended with $5 \mathrm{mM}$ acetate, $10 \mathrm{mM}$ fumarate, and $75 \mu \mathrm{M} \mathrm{U} \mathrm{U}^{\mathrm{VI}}$, incubated for 14 days. Controls used the same mineral salts medium amended with $100 \mu \mathrm{M} \mathrm{U} \mathrm{U}^{\mathrm{VI}}$ but without bacteria and electron donor. Duplicates of the controls 
were subsequently used for abiotic reduction experiments with $1 \mathrm{mM} \mathrm{AH} \mathrm{AH}_{2} \mathrm{QDS}$. Independent experiments exploring $\mathrm{U}^{\mathrm{VI}}$ reduction by resting cells of $S$. putrefaciens strain $\mathrm{CN} 32$ were performed in $30 \mathrm{mM}$ bicarbonate medium with and without $4 \mathrm{mM}$ phosphate. Uranium concentrations in filtrates $(0.22 \mu \mathrm{m})$ were measured by inductively coupled plasma-optical emission spectroscopy using a Perkin-Elmer 4300DV ICP-OES. More detailed procedures are described in the Supporting Information.

Uranium Characterization. Uranium $\mathrm{L}_{\mathrm{III}}$-edge X-ray absorption near-edge structure (XANES) and EXAFS analyses were performed at the MRCAT/EnviroCAT beamline, ${ }^{27}$ Advanced Photon Source, Argonne National Laboratory. Insoluble U species are operationally defined here as $U$ in phases that did not pass through a $0.22-\mu \mathrm{m}$ membrane filter, which may include $\mathrm{U}$ in smaller particles that have either agglomerated, adhered to larger particles, or adhered to the membrane itself. The filtered hydrated solids were immediately sealed between layers of Kapton film inside an anoxic glovebox. Samples were transferred to a $\mathrm{N}_{2}$-purged chamber for room-temperature EXAFS measurements. The beamline undulator was tapered and the incident energy was scanned by using the $\mathrm{Si}(111)$ reflection of a doublecrystal monochromator. Energy calibration was maintained by the simultaneous collection of spectra from uranyl phosphate. $\mathrm{U}^{\mathrm{VI}}$ and $\mathrm{U}^{\mathrm{IV}}$ standards used in the analysis were carbonatecomplexed $\mathrm{U}^{\mathrm{VI}}$ in solution and a nonuraninite $\mathrm{U}^{\mathrm{IV}}$ produced by reaction of $\mathrm{U}^{\mathrm{VI}}$ with green rust (XANES standards), crystalline uraninite diluted in $\mathrm{SiO}_{2}{ }^{28}$ and previously characterized nanouraninite produced by $S$. putrefaciens $\mathrm{CN} 32$ or green rust. ${ }^{19,22}$ Additional details are provided in the Supporting Information.

\section{RESULTS AND DISCUSSION}

Soluble $U^{\mathrm{VI}}$. In phosphate-amended media, Shewanella, Anaeromyxobacter, and Desulfitobacterium spp. removed $>80 \%$ of the initial $\mathrm{U}^{\mathrm{VI}}$ dose after 14-20 days (Table 1). Previous work with Desulfitobacterium spp. in phosphate-amended media demonstrated attainment of steady state $U$ concentrations after 9 days. ${ }^{7}$ In contrast, no more than $50 \%$ of $\mathrm{U}^{\mathrm{VI}}$ was removed in phosphatefree media after $12-15$ days. The observed small deviations in removed $\mathrm{U}^{\mathrm{VI}}$ within each treatment are presumably due to slight differences in cell densities, reduction rates, and/or reaction times that were not normalized between the experiments with different Desulfitobacterium strains. $\mathrm{U}^{\mathrm{VI}}$ was also removed from solution by $\mathrm{AH}_{2} \mathrm{QDS}$, with more $\mathrm{U}^{\mathrm{VI}}$ removed in phosphateamended than in phosphate-free medium. The observed effect of phosphate on $\mathrm{U}^{\mathrm{VI}}$ removal in the presence of reductants is discussed after presentation of the results on the valence of solid-associated $\mathrm{U}$ (below). Less than $12 \%$ of $\mathrm{U}^{\mathrm{VI}}$ was removed from solution in uninoculated, $\mathrm{AH}_{2} \mathrm{QDS}$-free controls over the same period, with slightly larger amounts of $\mathrm{U}^{\mathrm{VI}}$ removed in phosphate-containing controls. The latter indicates very limited formation of $\mathrm{U}^{\mathrm{VI}}$-phosphate precipitates in the presence of $30 \mathrm{mM}$ dissolved bicarbonate, consistent with solubility calculations for uranyl phosphate, uranyl hydrogen phosphate, and autunite minerals (Supporting Information, section 11).

XANES and EXAFS Analysis of the Insoluble Uranium Species. XANES spectra of solid-phase U from Desulfitobacterium incubations in phosphate-free medium are shown in Figure 1A. Solid-phase U recovered from all five Desulfitobacterium strains yielded similar spectra matching the nonuraninite $\mathrm{U}^{\mathrm{IV}}$ XANES standard. The XANES spectra of $U$ precipitated by $\mathrm{AH}_{2}$ QDS also indicated $\mathrm{U}^{\mathrm{IV}}$ in the solid phase (Figure 1B). Parts

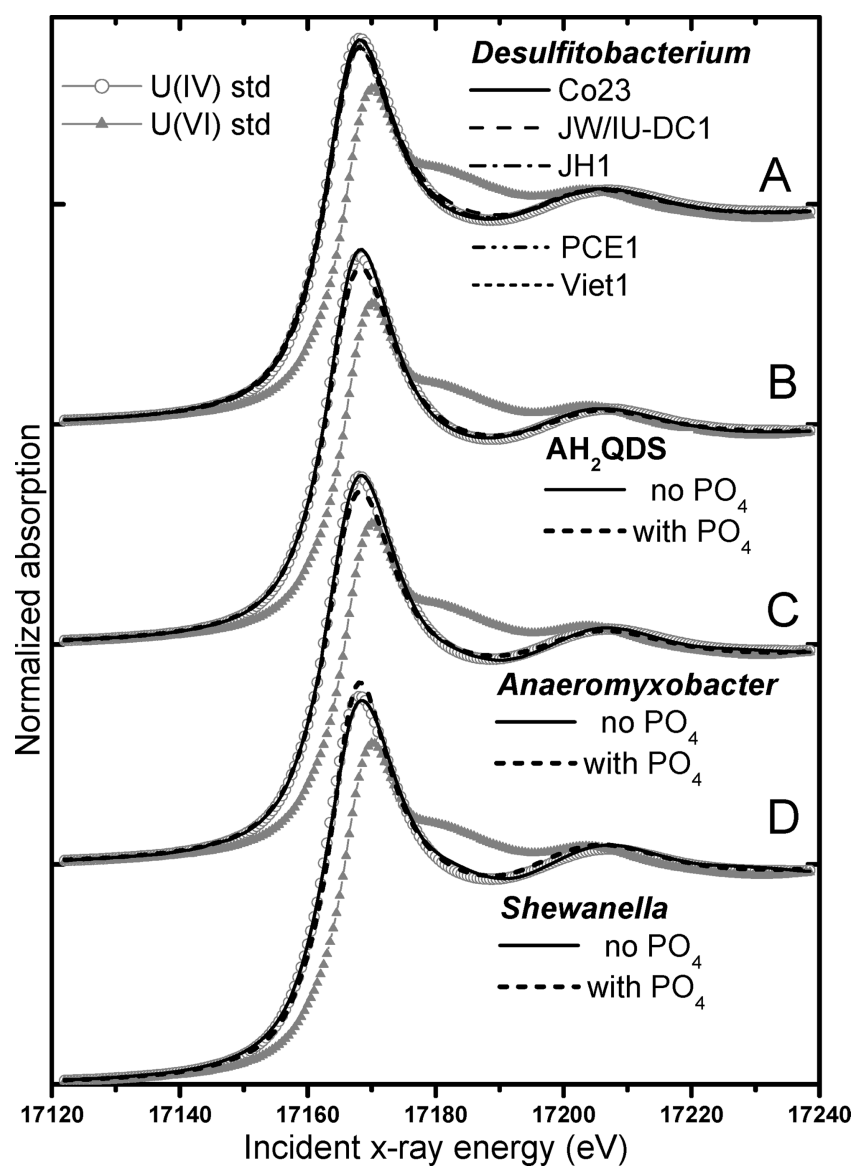

Figure 1. Uranium $\mathrm{L}_{\mathrm{III}}$-edge XANES data obtained from biotic and abiotic systems (black lines) compared to $\mathrm{U}^{\mathrm{IV}}$ and $\mathrm{U}^{\mathrm{VI}}$ standards (gray symbols). In all cases, the dark lines overlie each other and the $U^{\mathrm{IV}}$ standard. (A) Desulfitobacterium cultures in phosphate-free medium. (B) $\mathrm{AH}_{2} \mathrm{QDS}$ in phosphate-free and phosphate-amended medium. (C) $A$. dehalogenans 2CP-C in phosphate-free and phosphate-amended medium. (D) S. putrefaciens CN32 in phosphate-free and phosphateamended medium.

$\mathrm{C}$ and D of Figure 1 respectively show XANES spectra of $U$ precipitated by Anaeromyxobacter and Shewanella. The spectra overlie the $\mathrm{U}^{\mathrm{IV}}$ standard but show slight postedge differences between phosphate-free and phosphate-amended media incubations. These differences are related to the presence or absence of $\mathrm{U}-\mathrm{U}$ coordination between the $\mathrm{U}^{\mathrm{IV}}$ atoms (see EXAFS analysis below) and could be used for identification of uraninite vs nonuraninite $\mathrm{U}^{\mathrm{IV}}$ based on XANES data alone. XANES analysis of samples from our previous work with phosphate-amended Desulfitobacterium cultures also indicated the precipitation of $\mathrm{U}^{\mathrm{IV}}$ species. ${ }^{7}$ In summary, XANES data indicated reduction to $\mathrm{U}^{\mathrm{IV}}$ in all systems (Table 1). Phosphate increased the extent of $\mathrm{U}^{\mathrm{VI}}$ removal from solution, but precipitation as $\mathrm{U}^{\mathrm{IV}}$ was observed in both phosphate-free and phosphate-amended incubations. Unreduced $U^{\mathrm{VI}}$-phosphate precipitates were not observed in any of the studied systems.

Figure 2A shows Fourier-transformed (FT) EXAFS data from $\mathrm{U}^{\mathrm{IV}}$ generated by the Desulfitobacterium cultures in phosphatefree medium. The spectra overlie each other, indicating that identical $\mathrm{U}^{\mathrm{IV}}$ species were generated by all five Desulfitobacterium strains. The differences from the uraninite standard are in the amplitude of the first O shell at $R+\Delta=1.75 \AA$ (feature "a") and 


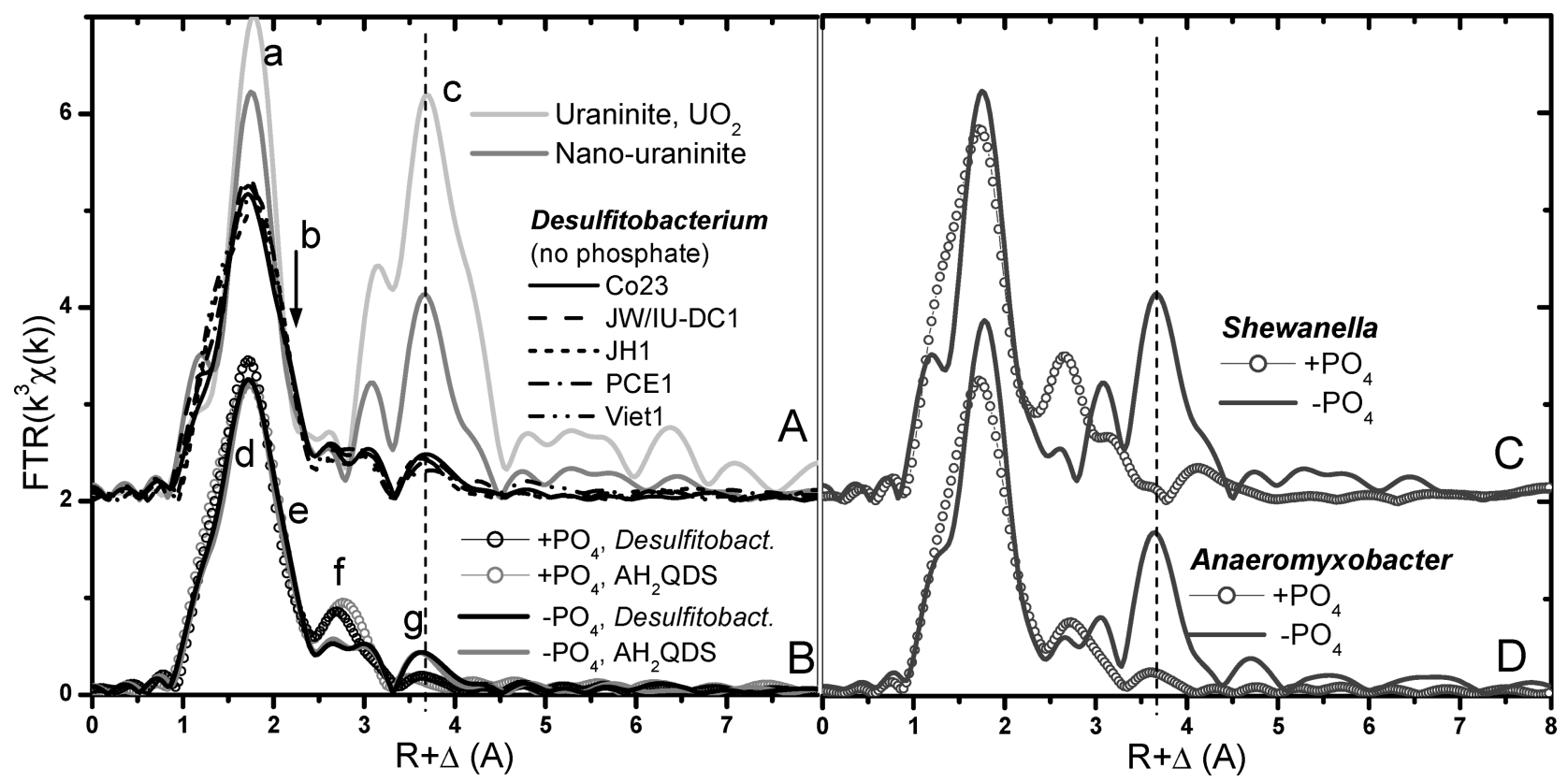

Figure 2. Fourier transforms of $k^{3}$-weighed EXAFS data over the range $\Delta k=2.0-10.2 \AA^{-1}$ and a Hanning window of $1.0 \AA^{-1}$. The features noted by lower-case letters are discussed in the text. (A) $\mathrm{U}^{\mathrm{IV}}$ produced by five Desulfitobacterium strains in phosphate-free medium (black lines) compared to a uraninite and a nano-uraninite standard (gray). (B) $\mathrm{U}^{\mathrm{IV}}$ produced by reduction with Desulfitobacterium sp. and $\mathrm{AH}_{2} \mathrm{DS}$ in phosphate-amended (symbols) and in phosphate-free (lines) medium. (C) $\mathrm{U}^{\mathrm{IV}}$ produced by reduction with S. putrefaciens $\mathrm{CN} 32$ in phosphate-amended (symbols) and phosphate-free (line) medium. (D) $\mathrm{U}^{\mathrm{IV}}$ produced by reduction with A. dehalogenans $2 \mathrm{CP}-\mathrm{C}$ in phosphate-amended (symbols) and phosphate-free (line) medium.

the amplitude of the doublet at $R+\Delta=3.0-4.0 \AA$, where the $U$ shell at $R=3.87 \AA$ contributes (feature "c"). A shoulder to the right of the main peak (feature " $b$ ") is also visible in the spectra of solid-phase U from Desulfitobacterium cultures in phosphate-free medium (detailed view in Figure S4, Supporting Information). The U-U feature $\mathrm{c}$ is much smaller in spectra from Desulfitobacterium cultures than in spectra from the uraninite standards. A decrease of approximately $50 \%$ in the amplitude of feature $\mathrm{c}$ in nano-uraninite relative to bulk uraninite (Figure 2A) occurs when uraninite is in the form of $2-5 \mathrm{~nm}$ particles. ${ }^{18,19}$ The much smaller amplitude of feature $c$ in spectra from Desulfitobacterium cultures suggests that only a fraction of the $\mathrm{U}^{\mathrm{IV}}$ atoms are present as nano-uraninite, the predominant solid-phase $\mathrm{U}^{\mathrm{IV}}$ being a species that lacks the $\mathrm{U}=\mathrm{O}_{2}=\mathrm{U}$ coordination of uraninite.

Figure $2 \mathrm{~B}$ compares data from $\mathrm{U}^{\mathrm{IV}}$ produced in phosphatefree and phosphate-amended media, both in Desulfitobacterium cultures and in abiotic incubations with $\mathrm{AH}_{2} \mathrm{QDS}$. Only one biotic spectrum is shown for each phosphate condition because all five Desulfitobacterium strains produced essentially identical $\mathrm{U}^{\mathrm{IV}}$ spectra in each treatment. Small but consistent differences were observed between $\mathrm{U}^{\mathrm{IV}}$ produced in phosphate-free and phosphate-amended media (Figure 2B). The differences are significant, because their amplitudes are larger than the noise in the spectra, as well as larger than the scatter between five separate measurements on samples from five Desulfitobacterium strains (see Figure 2A for phosphate-free and Figure $3 \mathrm{~B}$ in Fletcher et al. ${ }^{\mathcal{1}}$ for the phosphate-amended condition). The spectral differences suggest that (1) different atomic environments are present around $\mathrm{U}^{\mathrm{IV}}$ in phosphate-free and phosphateamended media (features "d" and "e"; details in Figure S4, Supporting Information); (2) an additional atomic shell is present around $\mathrm{U}^{\mathrm{IV}}$ atoms produced in phosphate-amended incubations (FT peak at $2.7 \AA$, feature "f"), but not around $\mathrm{U}^{\mathrm{IV}}$ atoms produced in phosphate-free incubations; and (3) an additional atomic shell is present around $\mathrm{U}^{\mathrm{IV}}$ atoms produced in phosphate-free medium (FT amplitude at $3.6 \AA$, feature " $g$ "), but not around $\mathrm{U}^{\mathrm{IV}}$ atoms produced in phosphate-amended medium. Qualitative analysis of feature g suggested that it was due to a small $U$ shell contribution (assumed to result from a fraction of the $U$ atoms being in the nano-uraninite structure and quantified below), whereas no U contribution was seen in spectra from phosphate-amended samples (Figure S3, Supporting Information). Analysis of the EXAFS data revealed that the highfrequency features seen with uraninite were not visible in spectra from the Desulfitobacterium or $\mathrm{AH}_{2}$ QDS systems; a small phase shift was evident in the range $4-7 \AA^{-1}$ between the phosphatefree and phosphate-amended samples, corroborating the formation of different nonuraninite $\mathrm{U}^{\mathrm{IV}}$ species under the two conditions (Figure S1, Supporting Information).

The $\mathrm{U}^{\mathrm{IV}}$ species generated in Desulfitobacterium cultures and in $\mathrm{AH}_{2} \mathrm{QDS}$ incubations were compared to those produced in Shewanella and Anaeromyxobacter cultures (Figure 2C,D). In phosphate-free medium both Shewanella and Anaeromyxobacter cultures produced nano-uraninite, as has been observed previously. ${ }^{8,18,19}$ In phosphate-amended samples, the U peak at 3.6 $\AA$ vanished and a peak similar to feature $\mathrm{f}$ in the phosphateamended Desulftibacterium cultures (see Figure 2B) appeared, suggesting a similar coordination environment of the $\mathrm{U}^{\mathrm{IV}}$ atoms in all phosphate-amended cultures. The data for Shewanella and Anaeromyxobacter demonstrate that these bacteria formed uraninite in phosphate-free medium and a nonuraninite $\mathrm{U}^{\mathrm{IV}}$ species in phosphate-amended medium. The spectral differences between the phosphate-amended systems in Figure 2C,D are likely 


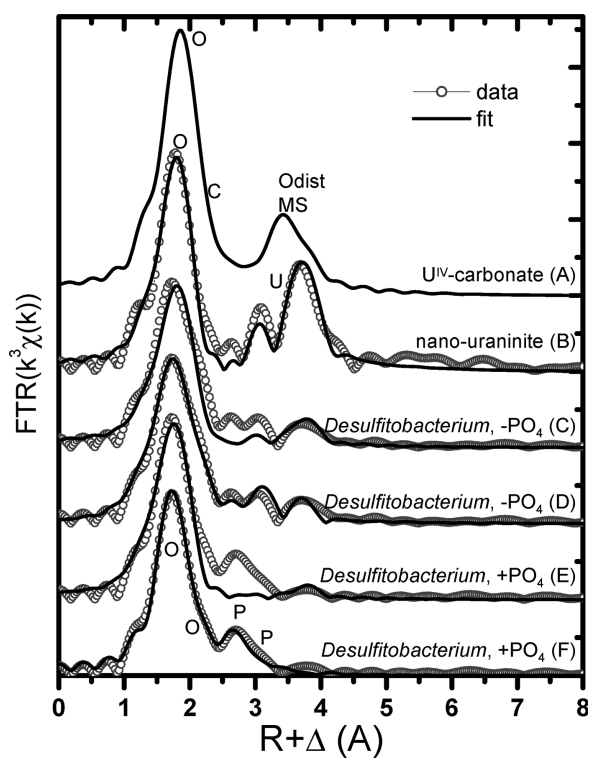

Figure 3. Fits of the EXAFS data obtained from bioreduced $\mathrm{U}^{\mathrm{IV}}$ species. The fit paths and parameters are listed in Table S2, Supporting Information. The contributions of some atomic shells are noted. The circles indicate measured data, and the lines indicate the best fit. (A) Numerical reproduction of the $\mathrm{U}^{\mathrm{IV}}$-carbonate spectrum fit in Hennig et al. ${ }^{32}$ (B) Data and fit for the nano-uraninite standard. (C) Desulfitobacterium $\mathrm{sp}$. without phosphate fitted with the nano-uraninite model. (D) Desulfitobacterium sp. without phosphate fitted with the combined $\mathrm{U}^{\mathrm{IV}}$-carbonate and uraninite model. (E) Desulfitobacterium sp. with phosphate fitted with the nano-uraninite model. (F) Desulfitobacterium sp. with phosphate fitted with a $\mathrm{U}^{\mathrm{IV}}$-phosphate model.

due to the difference in phosphate concentrations (i.e., $4.0 \mathrm{mM}$ for Shewanella vs $0.3 \mathrm{mM}$ for Anaeromyxobacter), suggesting that future work should explore the effects of high phosphate concentrations on solid-phase $\mathrm{U}^{\mathrm{IV}}$ formation. Phosphate concentrations in the millimolar range have been observed as a result of phosphatase activity of bacteria isolated from field-sites during incubations aimed at $\mathrm{U}^{\mathrm{VI}}$-phosphate precipitation. ${ }^{29,30}$ For the remainder of this work, only Desulfitobacterium and Anaeromyxobacter are compared, because they were incubated under similar low-phosphate solution conditions. The Gram-positive Desulfitobacterium cultures and the Gram-negative Anaeromyxobacter cultures produced the same nonuraninite $\mathrm{U}^{\mathrm{IV}}$ species in phosphateamended medium. In phosphate-free medium Anaeromyxobacter formed nano-uraninite, whereas a nonuraninite $\mathrm{U}^{\mathrm{IV}}$ species was produced in Desulfitobacterium cultures.

Numerical fits to the EXAFS data were based on a model that reproduced well the spectrum from nano-uraninite (Figure 3B and Supporting Information, section 6). The U-U coordination number of this $\mathrm{O}$ and $\mathrm{U}$ shell "nano-uraninite model" was refined in all samples to quantify the proportion of nano-uraninite in the solid phase. A fit of the spectrum from $\mathrm{U}^{\mathrm{IV}}$ produced in phosphate-free medium with the nano-uraninite model is shown in Figure 3C (for more details see Figure S7, Supporting Information). The $\mathrm{U}$ shell contribution suggested by the qualitative analysis is seen in the small but nonzero $\mathrm{U}-\mathrm{U}$ coordination number $(1.3 \pm 0.7$, Table $S 2-C)$. The $U-U$ coordination is much smaller than in the nano-uraninite standard $(5.0 \pm 1.9)$, thus corroborating that the dominant $\mathrm{U}^{\mathrm{IV}}$ species produced in phosphate-free medium was not nano-uraninite. The fit in Figure $3 \mathrm{C}$ demonstrates that an $\mathrm{O}$ shell alone is not sufficient to reproduce the shoulder on the right-hand side of the main peak, suggesting the presence of atoms from a complexing ligand in the $\mathrm{U}^{\mathrm{IV}}$ environment. Adsorption of $\mathrm{U}^{\mathrm{IV}}$ to sites on the cell surface (which are abundant and ionized at circumneutral $\mathrm{pH}^{31}$ ) could be excluded because identical spectra were obtained with samples from the Desulfitobacterium cultures and from the sterile, $\mathrm{AH}_{2} \mathrm{QDS}$-amended system (Figure 2B). The presence of bicarbonate in the media suggested the possibility of $\mathrm{U}^{\mathrm{IV}}$-carbonate complexation in the solid phase. As described in the Supporting Information (section 7), a good fit of the spectrum obtained from $\mathrm{U}^{\mathrm{IV}}$ in phosphate-free medium systems was produced with a linear combination of the nano-uraninite model and a model based on the structure of $\mathrm{U}^{\mathrm{IV}}$-carbonate ${ }^{32}$ (Figure 3D and Table S2, Supporting Information). The refined fraction of the $\mathrm{U}^{\mathrm{IV}}$ carbonate spectral component was $x=0.62 \pm 0.12$ (Table S2, Supporting Information) suggesting that a significant portion $(62 \% \pm 12 \%)$ of the atoms resulting from $\mathrm{U}^{\mathrm{VI}}$ reduction by Desulfitobacterium or $\mathrm{AH}_{2} \mathrm{QDS}$ in phosphate-free medium are present as a carbonate-complexed $\mathrm{U}^{\mathrm{IV}}$ species.

A "nano-uraninite model" fit of the spectrum obtained from $\mathrm{U}^{\mathrm{IV}}$ in phosphate-amended systems is shown in Figure 3E, with additional details presented in Table S2-E and Figure S8 (Supporting Information). The obtained $\mathrm{U}-\mathrm{U}$ coordination number of $0.6 \pm 0.8$ is consistent with 0 and confirms that nano-uraninite was not present as a significant phase in the system. Previous work demonstrated that the structure between $R+\Delta$ values of 2.5 and $3.5 \AA$ (feature $\mathrm{f}$ ) can be reproduced equally well by a combination of two $\mathrm{O}$ or two $\mathrm{P}$ shells. ${ }^{7}$ This ambiguity was resolved in this study by comparisons with experiments in phosphate-free medium. The fact that the FT peak around $R+\Delta=2.7 \AA$ was apparent in nonuraninite spectra only in the presence of phosphate suggests that this signal was due to $\mathrm{P}$ atoms from $\mathrm{U}^{\mathrm{IV}}$-phosphate complexation. The best fit of the spectrum was obtained with a model based on the structure of ningyoite, a CaU ${ }^{\mathrm{IV}}\left(\mathrm{PO}_{4}\right)_{2}$ mineral $^{33}$ (Figure 3F and details in Figure S11 and Table S2-F, Supporting Information). The ningyoite structure consists of $\mathrm{U}^{\mathrm{IV}}$ atoms in monodentate and bidentate bonds to phosphate groups (Figure S7, Supporting Information).

Phosphate Controls $U^{\mathrm{IV}}$ Species Formation. $\mathrm{U}^{\mathrm{VI}}$ bioreduction studies with Shewanella, Anaeromyxobacter, and Geobacter spp. commonly report nano-uraninite as the product from resting cell incubations in phosphate-free medium. ${ }^{8,10,12,18-20,34,35}$ Electron microscopy in these previous studies showed nano-uraninite localized in the periplasm or associated with extracellular polymeric substances, and the $U$ peak at $R+\Delta=3.6 \AA$ was evident in the EXAFS data. Recent work demonstrated that nano-uraninite produced by Shewanella oneidensis MR-1 did not dissolve significantly in $1 \mathrm{M}$ bicarbonate solution, ${ }^{36}$ suggesting that biogenic nano-uraninite does not contain significant nonuraninite species (on the basis of a bicarbonate extraction test ${ }^{37}$ ).

The results of the current study corroborate the formation of uraninite by Shewanella and Anaeromyxobacter spp. in phosphatefree medium. However, the addition of phosphate prevented the formation of uraninite and caused the formation of a $\mathrm{U}^{\mathrm{IV}}$ phosphate species. At low phosphate:uranium molar ratios (3:1), the Gram-positive Desulfitobacterium strains, the Gramnegative Anaeromyxobacter, and the soluble reductant $\mathrm{AH}_{2} \mathrm{QDS}$ produced the same nonuraninite $\mathrm{U}^{\mathrm{IV}}$-phosphate species. Abiotic $\mathrm{U}^{\mathrm{VI}}$ reduction experiments with $\mathrm{Fe}^{\mathrm{II}}$ as the reductant also showed that phosphate:uranium molar ratios as low as 1:1 can change the $\mathrm{U}^{\mathrm{IV}}$ product from uraninite to phosphate-complexed $\mathrm{U}^{\mathrm{IV}} \cdot 38$ 

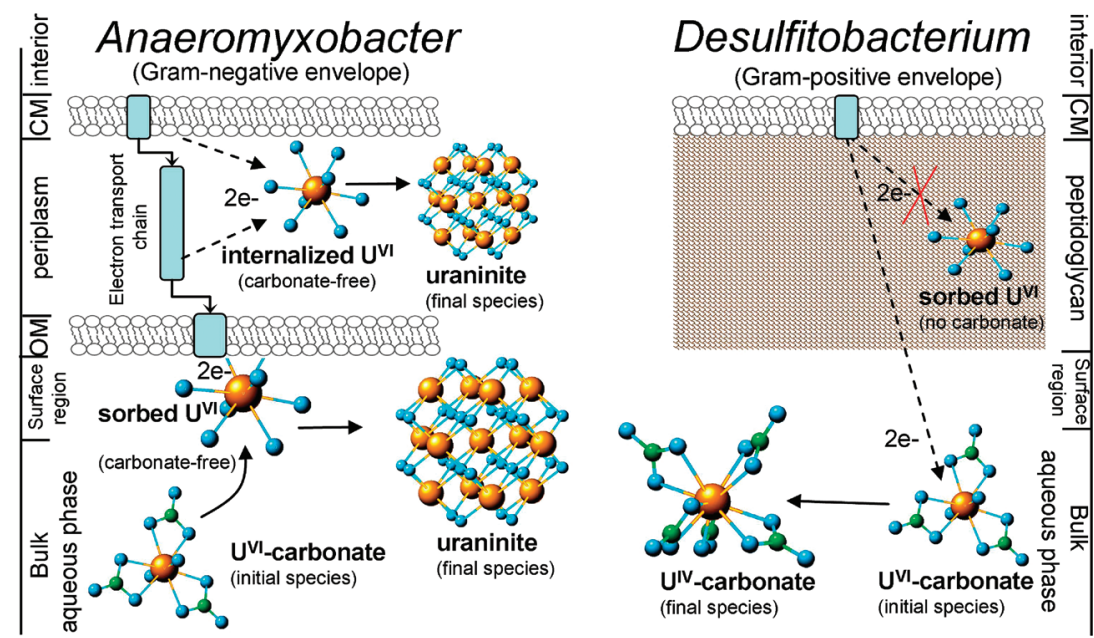

Figure 4. Proposed mechanisms of uranyl reduction in A. dehalogenans and Desulfitobacterium sp., based on the observed $\mathrm{U}^{\mathrm{IV}}$ products and the state of knowledge on electron transfer mechanisms and locations of reduced U in Gram-positive and Gram-negative bacteria. Spatial locations are schematically delineated on the axes to the left and right. Dashed arrows indicate tentative electron transfer pathways. CM = cytoplasmic (inner) membrane and $\mathrm{OM}=$ outer membrane.

These findings indicate that small amounts of phosphate can have a controlling effect on $\mathrm{U}^{\mathrm{IV}}$ speciation. Elevated phosphate concentrations are relevant to $\mathrm{U}$ in natural environments containing phosphate minerals (e.g., apatite), ${ }^{39}$ in phosphate-bearing permeable reactive barriers, ${ }^{40,41}$ or as the result of cell phosphatase activity in cells. ${ }^{26,29,30,42}$ The significance of $\mathrm{U}^{\mathrm{IV}}$ phosphate formation is that nonuraninite $\mathrm{U}^{\mathrm{IV}}$ species may behave differently in the subsurface (e.g., be released more easily into solution than uraninite). ${ }^{37}$ Evidence of $\mathrm{U}^{\mathrm{IV}}$-phosphate formation during bioreduction of $\mathrm{U}^{\mathrm{VI}}$ is accumulating $7,15,25,26,43$ and its role in controlling $U$ mobility in the subsurface will need to be addressed. Interestingly, the mineral ningyoite $\left[\mathrm{CaU}^{\mathrm{IV}}\right.$ $\left.\left(\mathrm{PO}_{4}\right)_{2}\right]$ in uranium ores is formed under more oxidizing conditions than is uraninite or coffinite. ${ }^{44}$ This suggests that $\mathrm{U}^{\mathrm{IV}}$-phosphate species might be the first to form in phosphatecontaining systems when conditions shift from oxidizing to reducing. Besides affecting the speciation of $\mathrm{U}^{\mathrm{IV}}$, the presence of phosphate also increased the extent of $\mathrm{U}^{\mathrm{VI}}$ removal from solution in both the biotic and abiotic systems in this study (Table 1). In biotic systems, it is not clear whether the effect of phosphate was (1) to facilitate the electron transfer reaction "reactants $\rightarrow$ products" by changing the speciation of the reactants and/or products or (2) to facilitate bacterial metabolism and consequently increase $\mathrm{U}^{\mathrm{VI}}$ reduction rates. $\mathrm{U}^{\mathrm{VI}}$ speciation in biotic systems is complex due to the presence of the bacterial surfaces, and it is not known whether electrons are transferred to the soluble or adsorbed $\mathrm{U}^{\mathrm{VI}}$ species. Some insight on the reducibility of dissolved $\mathrm{U}^{\mathrm{VI}}$ species in the presence of phosphate can be obtained from the abiotic experiments with $\mathrm{AH}_{2} \mathrm{QDS}$ as the reductant. The extent of abiotic removal of $\mathrm{U}^{\mathrm{VI}}$ from solution by $\mathrm{AH}_{2} \mathrm{QDS}$ was larger in the presence than in the absence of phosphate (Table 1), suggesting either that $\mathrm{U}^{\mathrm{IV}}$ phosphate species are formed more easily or that $\mathrm{U}^{\mathrm{VI}}$-phosphate species are reduced more easily by $\mathrm{AH}_{2} \mathrm{QDS}$.

The $U^{\mathrm{IV}}$ Product in Phosphate-Free Media Is Indicative of the $U^{\mathrm{VI}}$ Reduction Mechanism. The formation of any $U$ species is controlled by the local chemical conditions where the reactions take place (e.g., $\mathrm{pH}$, metal and ligand concentrations, ionic strength). These conditions could be different near a cell relative to the known solution composition. The concentrations of ions in the electrostatic double layer near a cell surface can differ from those in the bulk matrix, and diffusion limitations near the bacterial surface may prevent equilibration with the bulk solution. ${ }^{45}$ The observed differences between the $\mathrm{U}^{\mathrm{IV}}$ species produced by Anaeromyxobacter and by the Desulfitobacterium strains in the same phosphate-free medium suggest $\mathrm{U}^{\mathrm{IV}}$ formation under presumably different chemical conditions at different locations (e.g., at or near the cell wall or in the bulk solution), which in turn suggests differences in the biomolecular mechanism involved in electron transfer to $\mathrm{U}^{\mathrm{VI}}$.

Some insight may be obtained from the cell wall architecture. Both Gram-positive and Gram-negative cells carry negatively charged groups on the exterior, suggesting anion depletion in the solution layer near the surface. ${ }^{46}$ The predominant $\mathrm{U}^{\mathrm{VI}}$ species in bicarbonate solutions is the negatively charged $\mathrm{U}^{\mathrm{VI}}$-triscarbonato complex (Figure S14, Supporting Information). Proximity of $\mathrm{U}^{\mathrm{VI}}$-carbonate species and of carbonate anions to a negatively charged surface is discouraged by electrostatic repulsion, so the environment near the cell surface is likely to contain a larger proportion of the less-complexed neutral or positively charged $\mathrm{U}^{\mathrm{VI}}$ species. The reduction of a carbonate-free uranyl in the anion-depleted environment of the cell surface would likely yield free $\mathrm{U}^{\mathrm{IV}}$ ions that can form uraninite, as observed here for Anaeromyxobacter and as typically observed with Shewanella and Geobacter spp. ${ }^{18,19,34,35}$ Although the presence of $\mathrm{Ca}^{2+}$ can lead to the formation of neutral $\mathrm{U}^{\mathrm{VI}}$-carbonate complexes that would not be affected by electrostatic repulsion, electron transfer to these stable, fully complexed species is inhibited. ${ }^{47,48}$ The hypothesis of carbonate-free $\mathrm{U}^{\mathrm{VI}}$ adsorption to the cell is also supported by abiotic $U^{\mathrm{VI}}$ sorption experiments to a carboxyl surface. No differences were observed between the EXAFS of $\mathrm{U}^{\mathrm{VI}}$ adsorbed to a carboxyl surface in the presence or absence of up to $30 \mathrm{mM}$ bicarbonate (Supporting Information, Figures S12 and S13), Although bicarbonate exerted significant control on the partitioning of $\mathrm{U}^{\mathrm{VI}}$ between the solution and the solid phase, the EXAFS spectra of the $\mathrm{U}^{\mathrm{VI}}$ species remaining on the surface were identical to that observed in the carbonate-free system. 
In contrast, if $\mathrm{U}^{\mathrm{VI}}$ reduction was occurring in the aqueous phase, then the solution composition would control the $\mathrm{U}^{\mathrm{IV}}$ product. In the absence of phosphate and surfaces, soluble $\mathrm{U}^{\mathrm{VI}}$ reduction by $\mathrm{AH}_{2} \mathrm{QDS}$ (a soluble reductant) was shown here to result in the formation of nonuraninite $\mathrm{U}^{\mathrm{IV}}$ species. The fact that under the same bulk solution conditions $\mathrm{U}^{\mathrm{VI}}$ reduction in the different Desulfitobacterium cultures resulted in the same $\mathrm{U}^{\mathrm{IV}}$ species as soluble $\mathrm{U}^{\mathrm{VI}}$ reduction with $\mathrm{AH}_{2} \mathrm{QDS}$ suggests that electrons were transferred to the dissolved $\mathrm{U}^{\mathrm{VI}}$ species rather than to the $\mathrm{U}^{\mathrm{VI}}$ species at or near the surface of Desulfitobacterium. The hypothesized differences in $\mathrm{U}^{\mathrm{VI}}$ reduction mechanisms between Anaeromyxobacter and the Desulfitobacterium strains may be explained by the different structures of Gram-negative and -positive cell walls. Gram-negative bacteria have outer membrane reductases exposed to the solution allowing direct electron transfer to both soluble and insoluble electron acceptors. ${ }^{21,49}$ In contrast, Gram-positive bacteria lack electron transport proteins at the outer surface, leading to the postulation of soluble mediator involvement in electron transfer to insoluble acceptors. ${ }^{9}$ Utilization of mediators for electron transfer by Desulfitobacterium spp. has been demonstrated by the generation of electricity in microbial fuel cells only in the presence of a soluble electron mediator. ${ }^{50} \mathrm{U}^{\mathrm{VI}}$ was provided predominantly as a soluble, carbonate-complexed species in all cultures in the current study, with no obvious hindrance for dissolved $\mathrm{U}^{\mathrm{VI}}$ to reach the cell-wall reductases. The observed differences in $\mathrm{U}^{\mathrm{IV}}$ products might have resulted from Anaeromyxobacter being able to reduce $\mathrm{U}^{\mathrm{VI}}$ only via direct contact with reductases at the surface, ${ }^{8}$ whereas indirect, mediator-dependent $\mathrm{U}^{\mathrm{VI}}$ reduction likely occurred in the Desulfitobacterium cultures. The mechanisms described above are illustrated in Figure 4, with a focus on the location of electron transfer to the $\mathrm{U}^{\mathrm{VI}}$ species as inferred from the obtained $\mathrm{U}^{\mathrm{IV}}$ products and the distinct cell wall architectures. The proposed electron transfer pathways are based on the state of knowledge of electron transfer in DMRB and the location of the precipitated $U$ in Gram-positive and Gramnegative bacteria. ${ }^{8,9,20,21,49}$ More detailed studies are warranted to elucidate the mechanistic and molecular differences in DMRB.

The different $\mathrm{U}^{\mathrm{VI}}$ reduction mechanisms illustrated in Figure 4 are largely consistent with the general differences in cell envelope architecture between Gram-positive and Gram-negative bacteria; thus, similar mechanisms may be governing $\mathrm{U}^{\mathrm{V}}$ reduction in other Gram-positive and Gram-negative bacteria. The formation of uraninite by many Gram-negative bacteria is well-established. $\mathrm{U}^{\mathrm{VI}}$ reduction by spores of the Gram-positive Desulfotomaculum reducens demonstrated that filtered medium from vegetative cells is necessary for $\mathrm{U}^{\mathrm{VI}}$ reduction to occur, suggesting the involvement of a low molecular weight redox mediator. ${ }^{59}$ An electron shuttle mechanism might also be operable in the reduction of $\mathrm{U}^{\mathrm{VI}}$ by Clostridium spp. Citrate complexation prevented both $\mathrm{U}^{\mathrm{VI}}$ sorption to the cell surface and $\mathrm{U}^{\mathrm{IV}}$ precipitation, ${ }^{14}$ suggesting that electron transfer occurred without contact between the cell and $\mathrm{U}^{\mathrm{VI}}$. The manifestation of different $\mathrm{U}^{\mathrm{VI}}$ reduction mechanisms might not always be clearly delineated along Gram stain and cell wall structure. Growth conditions could result in a change from mediated to direct contact reduction mechanisms or vice versa, or specific solution conditions (e.g., high ionic strength) could alter the ionic composition near the cell surface so that $\mathrm{U}^{\mathrm{IV}}$ atoms reduced at the surface are no longer produced in an environment depleted of solution ligands. For instance, the strong effect of phosphate observed in this and other studies suggests that, regardless of the pathway of $\mathrm{U}^{\mathrm{IV}}$ production, the presence of phosphate determines the formation of $\mathrm{U}^{\mathrm{IV}}$-phosphate species. Additionally, Marshall et al. ${ }^{8}$ showed electron donor dependence of the reduction rate and the morphology of nano-uraninite produced by $A$. dehalogenans $2 \mathrm{CP}-\mathrm{C}$ and proposed that different cell envelope $U^{V I}$ reductases could be operable under different electron donor conditions. Finally, $S$. oneidensis MR-1 has been shown to produce and utilize electron shuttles under specific conditions. ${ }^{52}$ The results of the current study demonstrate that determining the coordination environment of reduced $\mathrm{U}^{\mathrm{IV}}$ atoms provides insight into the chemical conditions of their formation, from which the mechanism of electron transfer to $\mathrm{U}^{\mathrm{VI}}$ can be inferred.

Implications for Uranium Bioremediation. The biogenic precipitation of $\mathrm{U}^{\mathrm{IV}}$ in species other than uraninite raises relevant questions for predicting the mobility and fate of uranium in contaminated subsurface environments. Uranium ${ }^{\mathrm{IV}}$-phosphate minerals appear to form under more oxidizing conditions than does uraninite in natural ores, ${ }^{44}$ so phosphate complexation may provide a more facile way of reducing $\mathrm{U}^{\mathrm{VI}}$. However, the solubility of $\mathrm{U}^{\mathrm{IV}}$ complexed by ligands will likely be greater than that of uraninite. ${ }^{37}$ Different reoxidation and resolubilization rates have been observed for nano-uraninite vs bulk uraninite, ${ }^{16,24,53}$ so $\mathrm{U}^{\mathrm{IV}}$-carbonate and $\mathrm{U}^{\mathrm{IV}}$-phosphate species are also likely to have specific remobilization properties. Detailed knowledge of the properties of $\mathrm{U}^{\mathrm{IV}}$ species is required to predict the postreduction stability of $\mathrm{U}^{\mathrm{V}}$. Our ongoing $\mathrm{U}^{\mathrm{VI}}$ reduction studies with sediments from the Oak Ridge National Laboratory field site showed that EXAFS spectra of $\mathrm{U}^{\mathrm{IV}}$ in biostimulated laboratory reactors and in extracted sediments after field-scale biostimulation do not have the diagnostic $\mathrm{U}-\mathrm{U}$ peak and are not nano-uraninite. ${ }^{54,55}$ The $\mathrm{U}^{\mathrm{IV}}$ products and reduction mechanisms identified here are therefore relevant to the detection and fate of reduced uranium in natural and engineered environments.

\section{ASSOCIATED CONTENT}

S Supporting Information. Details regarding the experimental procedures, EXAFS data collection and analysis, molecular structures of the minerals used in the analysis, and $\mathrm{U}^{\mathrm{VI}}$ speciation calculations. This material is available free of charge via the Internet at http://pubs.acs.org/.

\section{AUTHOR INFORMATION}

\section{Corresponding Author}

*Phone: (630)252-8242; fax: (630)252-9793; e-mail: mboyanov@ anl.gov.

\section{Present Addresses}

${ }^{\nabla}$ Korea Institute of Science and Technology, Gangneung, 210340 , S. Korea.

\section{ACKNOWLEDGMENT}

We thank B. Mishra and T. Shibata for help during EXAFS data collection. Correspondence with O. Doinikova regarding the mineralogy of uranium ores is appreciated. Research under the Subsurface Science Focus Area program at Argonne National Laboratory was supported by the Subsurface Biogeochemical Research Program, Office of Biological and Environmental Research (BER), Office of Science, U.S. Department of Energy (DOE), under contract DE-AC02-06CH11357. Additional DOE funding was provided by the U.S. DOE BER, Environmental 
Remediation Sciences Program (grant numbers ER63718 and ER64782). Use of the APS was supported by the U.S. Department of Energy, Office of Science, Office of Basic Energy Sciences, under contract DE-AC02-06CH11357. MRCAT/EnviroCAT operations are supported by $\mathrm{DOE}$ and the member institutions. K.E.F. acknowledges support through an NSF graduate research fellowship. M.J.K. was supported by an Argonne Director's Fellowship and the KIST-Gangneung Institute (Grant 2Z03402)

\section{REFERENCES}

(1) Batson, V. L.; Bertsch, P. M.; Herbert, B. E. Transport of anthropogenic uranium from sediments to surface waters during episodic storm events. J. Environ. Qual. 1996, 25, 1129-1137.

(2) Riley, R. G.; Zachara, J. M.; Wobber, F. J. DOE/ER-0547T. U.S. Department of Energy, 1992.

(3) Landa, E. R.; Gray, J. R. U.S. Geological Survey-Research on the environmental fate of uranium mining and milling wastes. Environ. Geol. 1995, 26, 19-31.

(4) Langmuir, D. Uranium solution-mineral equilibria at low temperatures with applications to sedimentary ore deposits. Geochim. Cosmochim. Acta 1978, 42, 547-569.

(5) Fang, Y.; Yabusaki, S.; Morrison, S.; Amonette, J.; Long, P. Multicomponent reactive transport modeling of uranium bioremediation field experiments. Geochim. Cosmochim. Acta 2009, 73, 6029-6051.

(6) Kelly, S. D.; Kemner, K. M.; Carley, J.; Criddle, C. S.; Jardine, P. M.; Marsh, T. L.; Phillips, D.; Watson, D.; Wu, W. M. Speciation of uranium in sediments before and after in situ biostimulation. Environ. Sci. Technol. 2008, 42, 1558-1564.

(7) Fletcher, K. E.; Boyanov, M. I.; Thomas, S. H.; Wu, Q. Z.; Kemner, K. M.; Löffler, F. E. U(VI) reduction to mononuclear U(IV) by Desulfitobacterium species. Environ. Sci. Technol. 2010, 44, 4705-4709.

(8) Marshall, M. J.; Dohnalkova, A. C.; Kennedy, D. W.; Plymale, A. E.; Thomas, S. H.; Löffler, F. E.; Sanford, R. A.; Zachara, J. M.; Fredrickson, J. K.; Beliaev, A. S. Electron donor-dependent radionuclide reduction and nanoparticle formation by Anaeromyxobacter dehalogenans strain 2CP-C. Environ. Microb. 2009, 11, 534-543.

(9) Ehrlich, H. L. Are Gram-positive bacteria capable of electron transfer across their cell wall without an externally available electron shuttle? Geobiology 2008, 6, 220-224

(10) Fredrickson, J. K.; Zachara, J. M.; Kennedy, D. W.; Duff, M. C.; Gorby, Y. A.; Li, S. M. W.; Krupka, K. M. Reduction of U(VI) in goethite (alpha-FeOOH) suspensions by a dissimilatory metal-reducing bacterium. Geochim. Cosmochim. Acta 2000, 64, 3085-3098.

(11) Gorby, Y. A.; Lovley, D. R. Enzymatic uranium precipitation. Environ. Sci. Technol. 1992, 26, 205-207.

(12) Lovley, D. R.; Phillips, E. J. P. Reduction of uranium by Desulfovibrio desulfuricans. Appl. Environ. Microbiol. 1992, 58, 850-856.

(13) Lovley, D. R.; Phillips, E. J. P. Bioremediation of uranium contamination with enzymatic uranium reduction. Environ. Sci. Technol. 1992, 26, 2228-2234.

(14) Francis, A. J.; Dodge, C. J. Bioreduction of uranium(VI) complexed with citric acid by Clostridia affects its structure and solubility. Environ. Sci. Technol. 2008, 42, 8277-8282.

(15) Bernier-Latmani, R.; Veeramani, H.; Vecchia, E. D.; Junier, P.; Lezama-Pacheco, J. S.; Suvorova, E. I.; Sharp, J. O.; Wigginton, N. S.; Bargar, J. R. Non-uraninite products of microbial U(VI) reduction. Environ. Sci. Technol. 2010, 44, 9456-9462.

(16) Suzuki, Y.; Kelly, S. D.; Kemner, K. M.; Banfield, J. F. Radionuclide contamination-Nanometre-size products of uranium bioreduction. Nature 2002, 419, 134-134.

(17) Suzuki, Y.; Kelly, S. D.; Kemner, K. M.; Banfield, J. F. Enzymatic $\mathrm{U}(\mathrm{VI})$ reduction by Desulfosporosinus species. Radiochim. Acta 2004, 92, 11-16.

(18) Schofield, E. J.; Veeramani, H.; Sharp, J. O.; Suvorova, E.; Bernier-Latmani, R.; Mehta, A.; Stahlman, J.; Webb, S. M.; Clark, D. L.;
Conradson, S. D.; Ilton, E. S.; Bargar, J. R. Structure of biogenic uraninite produced by Shewanella oneidensis strain MR-1. Environ. Sci. Technol. 2008, 42, 7898-7904.

(19) Burgos, W. D.; McDonough, J. T.; Senko, J. M.; Zhang, G. X.; Dohnalkova, A. C.; Kelly, S. D.; Gorby, Y.; Kemner, K. M. Characterization of uraninite nanoparticles produced by Shewanella oneidensis MR-1. Geochim. Cosmochim. Acta 2008, 72, 4901-4915.

(20) Marshall, M. J.; Beliaev, A. S.; Dohnalkova, A. C.; Kennedy, D. W.; Shi, L.; Wang, Z. M.; Boyanov, M. I.; Lai, B.; Kemner, K. M.; McLean, J. S.; Reed, S. B.; Culley, D. E.; Bailey, V. L.; Simonson, C. J.; Saffarini, D. A.; Romine, M. F.; Zachara, J. M.; Fredrickson, J. K. c-Type cytochrome-dependent formation of U(IV) nanoparticles by Shewanella oneidensis. PLoS. Biol. 2006, 4, 1324-1333.

(21) Wall, J. D.; Krumholz, L. R. Uranium reduction. Annu. Rev. Microbiol. 2006, 60, 149-166.

(22) O’Loughlin, E. J.; Kelly, S. D.; Cook, R. E.; Csencsits, R.; Kemner, K. M. Reduction of uranium(VI) by mixed iron(II/iron(III) hydroxide (green rust): Formation of $\mathrm{UO}_{2}$ nanoparticles. Environ. Sci. Technol. 2003, 37, 721-727.

(23) Boyanov, M. I.; O’Loughlin, E. J.; Roden, E. E.; Fein, J. B.; Kemner, K. M. Adsorption of Fe(II) and U(VI) to carboxyl-functionalized microspheres: The influence of speciation on uranyl reduction studied by titration and XAFS. Geochim. Cosmochim. Acta 2007, 71, 1898-1912.

(24) Bargar, J. R.; Bernier-Latmani, R.; Giammar, D. E.; Tebo, B. M. Biogenic uraninite nanoparticles and their importance for uranium remediation. Elements 2008, 4, 407-412.

(25) Khijniak, T. V.; Slobodkin, A. I.; Coker, V.; Renshaw, J. C.; Livens, F. R.; Bonch-Osmolovskaya, E. A.; Birkeland, N. K.; MedvedevaLyalikova, N. N.; Lloyd, J. R. Reduction of uranium(VI) phosphate during growth of the thermophilic bacterium Thermoterrabacterium ferrireducens. Appl. Environ. Microbiol. 2005, 71, 6423-6426.

(26) Sivaswamy, V.; Boyanov, M. I.; Peyton, B. M.; Viamajala, S.; Gerlach, R.; Apel, W.; Sani, R.; Dohnalkova, A. C.; Kemner, K. K.; Borch, T. Multiple mechanisms of uranium immobilization by Cellulomonas sp. strain ES6. Biotechnol. Bioeng. 2011, 108, 264-276.

(27) Segre, C. U.; Leyarovska, N. E.; Chapman, L. D.; Lavender, W. M.; Plag, P. W.; King, A. S.; Kropf, A. J.; Bunker, B. A.; Kemner, K. M.; Dutta, P.; Duran, R. S.; Kaduk, J. The MRCAT insertion device beamline at the Advanced Photon Source. In Synchrotron Radiation Instrumentation: Eleventh U.S. National Conference; Pianetta, P., Ed.; American Institute of Physics: New York, 2000; Vol. CP521, pp 419-422.

(28) Kelly, S. D.; Kemner, K. M.; Fein, J. B.; Fowle, D. A.; Boyanov, M. I.; Bunker, B. A.; Yee, N. XAFS determination of U-bacterial cell wall interaction at low pH. Abstr. Pap. Am. Chem. Soc. 2001, 221, 64-ENVR.

(29) Beazley, M.; Martinez, R.; Sobecky, P.; Webb, S.; Taillefert, M. Uranium biomineralization as a result of bacterial phosphatase activity: Insights from bacterial isolates from a contaminated subsurface. Environ. Sci. Technol. 2007, 41, 5701-5707.

(30) Beazley, M.; Martinez, R.; Sobecky, P.; Webb, S.; Taillefert, M. Nonreductive biomineralization of uranium(VI) phosphate via microbial phosphatase activity in anaerobic conditions. Geomicrobiology J. 2009, 26, 431-441.

(31) Fein, J. B.; Daughney, C. J.; Yee, N.; Davis, T. A. A chemical equilibrium model for metal adsorption onto bacterial surfaces. Geochim. Cosmochim. Acta 1997, 61, 3319-3328.

(32) Hennig, C.; Ikeda-Ohno, A.; Emmerling, F.; Kraus, W.; Bernhard, G. Comparative investigation of the solution species $\left[\mathrm{U}\left(\mathrm{CO}_{3}\right)_{5}\right]^{6-}$ and the crystal structure of $\mathrm{Na}_{6}\left[\mathrm{U}\left(\mathrm{CO}_{3}\right)_{5}\right] \cdot 12 \mathrm{H}_{2} \mathrm{O}$. Dalton Trans. 2010, 39, 3744-3750.

(33) Dusausoy, Y.; Ghermani, N. E.; Podor, R.; Cuney, M. Lowtemperature ordered phase of $\mathrm{CaU}\left(\mathrm{PO}_{4}\right)(2)$ : Synthesis and crystal structure. Eur. J. Mineral. 1996, 8, 667-673.

(34) Senko, J. M.; Kelly, S. D.; Dohnalkova, A. C.; McDonough, J. T.; Kemner, K. M.; Burgos, W. D. The effect of U(VI) bioreduction kinetics on subsequent reoxidation of biogenic U(IV). Geochim. Cosmochim. Acta 2007, 71, 4644-4654.

(35) Renshaw, J. C.; Butchins, L. J. C.; Livens, F. R.; May, I.; Charnock, J. M.; Lloyd, J. R. Bioreduction of uranium: Environmental 
implications of a pentavalent intermediate. Environ. Sci. Technol. 2005, 39, 5657-5660.

(36) Zhang, G.; Burgos, W. D.; Senko, J. M.; Bishop, M. E.; Dong, H.; Boyanov, M. I.; Kemner, K. K. Microbial reduction of chlorite and uranium followed by air oxidation. Chem. Geol. 2011, 283, 242-250.

(37) Alessi, D.; Uster, B.; Veeramani, H.; Stubbs, J.; LezamaPacheco, J.; Bargar, J. R.; Bernier-Latmani, R. Method to estimate the contribution of molecular $\mathrm{U}(\mathrm{IV})$ to the product of $\mathrm{U}(\mathrm{VI})$ reduction. Geochim. Cosmochim. Acta 2010, 74, A11.

(38) Boyanov, M. I.; O’Loughlin, E. J.; Kwon, M. J.; Mishra, B.; Rui, X.; Shibata, T.; Kemner, K. M. Mineral nucleation and redox transformations of $\mathrm{U}(\mathrm{VI})$ and $\mathrm{Fe}(\mathrm{II})$ species at a carboxyl surface. Geochim. Cosmochim. Acta 2010, 74, A115.

(39) Duerden, P. Alligator River Analogue Project, 1st Annual Report 1988-89. Australian Nuclear Science and Technology Organization (ANSTO). 1990.

(40) Fuller, C.; Bargar, J.; Davis, J.; Piana, M. Mechanisms of uranium interactions with hydroxyapatite: Implications for groundwater remediation. Environ. Sci. Technol. 2002, 36, 158-165.

(41) Naftz, D.; Morrison, S.; Feltcorn, E.; Freethey, G.; Fuller, C.; Piana, M.; Wilhelm, R.; Rowland, R.; Davis, J.; Blue, J. Field demonstration of permeable reactive barriers to remove dissolved uranium from groundwater, Fry Canyon, Utah. Interim Report, EPA, USGS, EPA 402C-00-001, 2000; www.epa.gov.

(42) Martinez, R.; Beazley, M.; Taillefert, M.; Arakaki, A.; Skolnick, J.; Sobecky, P. Aerobic uranium(VI) bioprecipitation by metal-resistant bacteria isolated from radionuclideand metal-contaminated subsurface soils. Environ. Microb. 2007, 9, 3122-3133.

(43) Lee, S. Y.; Baik, M. H.; Choi, J. W. Biogenic formation and growth of uraninite $\left(\mathrm{UO}_{2}\right)$. Environ. Sci. Technol. 2010, 44, 8409-8414.

(44) Doinikova, O. A. Uranium deposits with a new phosphate type of blacks. Geol. Ore Deposits 2007, 49, 80-86.

(45) Liu, C. X.; Zachara, J. M.; Felmy, A.; Gorby, Y. An electrodynamics-based model for ion diffusion in microbial polysaccharides. Colloid Surf. B-Biointerfaces 2004, 38, 55-65.

(46) Hart, T. D.; Lynch, J. M.; Chamberlain, A. H. L. Anion exclusion in microbial and soil polysaccharides. Biol. Fertil. Soils 2001, 34, 201-209.

(47) Brooks, S. C.; Fredrickson, J. K.; Carroll, S. L.; Kennedy, D. W.; Zachara, J. M.; Plymale, A. E.; Kelly, S. D.; Kemner, K. M.; Fendorf, S. Inhibition of bacterial U(VI) reduction by calcium. Environ. Sci. Technol. 2003, 37, 1850-1858.

(48) Stewart, B. D.; Mayes, M. A.; Fendorf, S. Impact of uranylcalcium-carbonato complexes on uranium(VI) adsorption to synthetic and natural sediments. Environ. Sci. Technol. 2010, 44, 928-934.

(49) DiChristina, T. J.; Fredrickson, J. K.; Zachara, J. M. Enzymology of electron transport: Energy generation with geochemical consequences. Mol. Geomicrobiol. 2005, 59, 27-52.

(50) Milliken, C. E.; May, H. D. Sustained generation of electricity by the spore-forming, Gram-positive, Desulfitobacterium hafniense strain DCB2. Appl. Microbiol. Biotechnol. 2007, 73, 1180-1189.

(51) Junier, P.; Frutschi, M.; Wigginton, N. S.; Schofield, E. J.; Bargar, J. R.; Bernier-Latmani, R. Metal reduction by spores of Desulfotomaculum reducens. Environ. Microb. 2009, 11, 3007-3017.

(52) Marsili, E.; Baron, D. B.; Shikhare, I. D.; Coursolle, D.; Gralnick, J. A.; Bond, D. R. Shewanella secretes flavins that mediate extracellular electron transfer. Proc. Natl. Acad. Sci. U. S. A. 2008, 105, 3968-3973.

(53) Ulrich, K. U.; Singh, A.; Schofield, E. J.; Bargar, J. R.; Veeramani, H.; Sharp, J. O.; Bernier-Latmani, R.; Giammar, D. E. Dissolution of biogenic and synthetic $\mathrm{UO}_{2}$ under varied reducing conditions. Environ. Sci. Technol. 2008, 42, 5600-5606.

(54) Boyanov, M. I.; O’Loughlin, E. J.; Kwon, M. J.; Skinner, K.; Mishra, B.; Criddle, C.; Wu, W.-M.; Yang, F.; Marsh, T.; Fletcher, K.; Loeffler, F.; Kemner, K. M. In 2010 ERSP PI Meeting Abstracts; DOE ERSP Program: Washington, DC, 2010; p 146.

(55) Wu, W.-M.; Watson, D.; Melhorn, T.; Earles, J.; Boyanov, M. I.; Gihring, T. M.; Ahang, G.; Schadt, C.; Lowe, K.; Phillips, J.; Kemner,
K. M.; Spalding, B.; Wu, Y.; Hubbard, S.; Baker, G.; Criddle, C.; Jardine, P.; Brooks, S. C. In 2010 ERSP PI Meeting Abstracts; DOE ERSP Program: Washington, DC, 2010; p 128. 